\section{Looking for drugs in ancient texts}

SIR - We wholeheartedly agree with the interesting possibilities raised by Bart K. Holland (Nature 369, 702; 1994). A new look at ancient texts may certainly help us to discover new and more efficient drugs.

Holland mentioned various manuscripts written by Chinese and Greeks. He might also have mentioned texts written by Hindus in India. The sages of that era (1000-100 BC) had a clear concept of different diseases and their treatment; for example, they could differentiate between intermittent and continous fevers and between diarrhoea and dysentery, using separate remedies for each. Medical texts such as the Caraka-Samihta and the Susruta-Samihta describe the use of more than a thousand plants in a wide range of diseases. They are available as Sanskrit and Hindi manuscripts and the remedies described in them are still used by practising Ayurvedic physicians in India ( $\mathrm{S}$. Gupta, Ayurvedic System of Medicine Vol. 1. N. N. Sen, Calcutta, 1909). The sad part is that Indians have lost faith in this system.

Interest has been rekindled in medicines from plants by the discovery of artemisinin from Artemisia annua for the treatment of malaria. A similar search of ancient Hindu texts would pay rich dividends in suggesting where to look for new pharmaceuticals.

\section{R. Sehgal}

Department of Clinical Parasitology,

Hospital for Tropical Diseases,

London NW1 OPE, UK.

\section{J. P. Ackers}

D. C. Warhurst

Department of Medical Parasitology,

London School of Hygiene

and Tropical Medicine,

London WC1E 7HT, UK

\section{Floods explained}

SiR - Your news story (Nature 369, 348; 1994) on the White House task force charged with framing a policy response to the Great Mississippi Flood of 1993 reveals that the focus of the draft version of their report is on floodplain and river management policies. Regrettably, it appears that the task force will ignore the broader landscape context, which is the profound human alteration of the natural hydrological cycle in the uplands.

The uplands of the Upper Mississippi and Missouri river watersheds originally consisted of native prairie, which has a high water-retention capacity. The native prairie has been completely replaced by intensive, industrialized, row-crop agriculture, resulting in a drastic reduction of the upland watershed's water-retention role in the hydrological cycle. Current agricultural practices increase surface runoff rate directly through the systems of drainage tiles, drainage ditches and channelling of smaller streams. Indirectly, present agricultural practices increase surface runoff through soil compaction, which reduces infiltration, and through replacement of native perennial vegetation (prairie) by annual crops, which reduces transpiration. Both the direct and indirect increases in surface runoff, combined with increased erosional sedimentation, exacerbate the problems associated with the constriction of floodplains by levees and the loss of floodplain wetlands.

Recognition of the profound agricultural alteration of the original upland watershed of the Upper Mississippi and Missouri rivers is critical if we are fully to understand the cause of the Great Mississippi Flood of 1993 and the likelihood of future such floods.

Angelo Capparella

Department of Biological Sciences, Illinois State University,

Normal, Illinois 61790-4120, USA

\section{No demons}

SIR - In his review of R. Steven Turner's book In the Eye's Mind: Vision and the Helmholtz-Hering Controversy (Nature 370, 259-260; 1994), C. R. Cavonius writes that: "It is unfortunate that an otherwise well-produced book has fallen into the clutches of that desktop publishing demon, the lost data-file: all bibliographic references to Helmholtz are missing. The publisher should try to make them available."

In fact, in the "Abbreviations" of the book's "Abbreviations and References" section, the author lists all of the necessary bibliographic references to Helmholtz's work.

\section{Emily Wilkinson}

Princeton University Press,

41 William Street,

Princeton, New Jersey 08540-5237, USA

\section{Counting time}

SIR - Cesare Emiliani (Nature 366, 716; 1994) proposes a new calendar that would start in the Late Glacial at what he calls a Human Era, instead of at the birth of Christ. An interesting and commendable idea indeed, which could make life somewhat easier for the Holocene stratigraphers, but more complicated for historians. As a supporting argument, Emiliani claims that the interval from -1.5 (or 1.5 $\mathrm{BC}$ ) to +1.5 (or $1.5 \mathrm{AD}$ ) cannot be computed by conventional algebraic methods because it covers only one and not three years.
I do not understand his mathematics. My understanding is that the $\mathrm{BC} / \mathrm{AD}$ boundary is taken arbitrarily as the last midnight of the year in which Christ is believed to have been born on 25 December. If so, then 1.5 years $\mathrm{AD}$ means 18 months following $00 \mathrm{Z}$ of 1 January of 1 $\mathrm{AD}$, or the midnight of 1 July of $2 \mathrm{AD}$. Correspondingly, 1.5 years $\mathrm{BC}$ means 18 months before that same timeline, which turns out to be July of the year 2 BC. That makes 36 months or three years altogether.

Sometimes we even hear about an intercalary year zero, which would extend the interval by another year. In no instance, however, can we come up with a single year for the corresponding timespan. Unless the year zero is inserted in the system, there should thus be little difficulty in computing time across the $\mathrm{BC} / \mathrm{AD}$ boundary by normal algebraic procedures.

\section{George Kukla}

Lamont-Doherty Earth Observatory,

Palisades, New York 10964, USA

\section{Masculine view}

SIR - In a recent Daedalus feature (Nature 370, 332; 1994), it is implied that a male brain without testosterone would be the equivalent of the female brain. A humorous experiment is then suggested, where male subjects would take a fictional drug, Neutermind, that denies testosterone access to the brain. Given the earlier premise and later comments, we must assume that Daedalus believes this state of mind, rather than being neuter, would actually more closely resemble a "femimind". The article notes that Freud would predict that these men's scientific creativity would summarily fade, although Daedalus stopped just short of advocating this viewpoint. It was stated, however, that if male criminals were given the drug they would turn into "placid, unadventurous citizens".

Ironically, just 12 pages away, you report that the government of India is attempting to reduce the practice of gender-selective abortion and that $50,000-80,000$ female fetuses are aborted every year after tests determine the gender of the fetus. In addition, you point out that female infanticide continues in India, where 6,000 baby girls have been murdered in one small community in Tamil Nadu over the past ten years.

If one of the world's preeminent scientific journals questions the value of women's minds, how does the government of India stand a chance of convincing its people of women's worth?

\section{Patricla Lod}

NIH/NIDDKLLP,

Bldg 5, Room B2-33,

5 Center Drive MSC-0505,

Bethesda, Maryland 20892-0505, USA 